This paper has been published in proceeding of The 1st International Symposium of Public Health "Emerging and Re-emerging Diseases. Nopember 30, 2016.

pages 190-197. S3 IImu Kesehatan, Fakultas Kesehatan Masyarakat, Universitas

Airlangga. Cetakan Pertama- Oktober 2017.

\title{
Correlation Between Blood Lead Level (BLL) And Osteoporosis in Postmenopausal Women In Surabaya Indonesia
}

Anita Dewi Moelyaningrum

Lecturer at Department of Environmental Health and Occupational Health and Safety,

School of Public Health University of Jember, East Java Indonesia.

Correspondence: Fakultas Kesehatan Masyarakat Universitas Jember.

Jl. Kalimantan I/ 93 Jember,

East Java- Indonesia 68121. Telp. 062 (0331) 337878, Fax. 062 (0331) 322995.

Email: anitamoelyani@gmail.com or anitadm@unej.ac.id;

\begin{abstract}
Lead $(\mathrm{Pb})$ compounds indicate that some toxic effects influence such as osteoporosis. This research was to identify the source of lead contamination and to analyze the association between blood lead level (BLL), a symptom of osteoporosis and occurrence of osteoporosis among post menopause women. A cross-sectional study was conducted in Surabaya City Indonesia. The sample size was 60 persons, randomly selected from post menopause women age 50-65 years. The observed variables were lead blood level, assessed using atomic absorption spectrophotometry (AAS) and bone mineral density of spine and hip, assessed using Dual X-Ray Examination Absorptiometry (DXA). The mean value of blood lead level was $11.135 \mu / \mathrm{dL}$. Multiple regression showed that there was a significant correlation between the history of work and Blood lead level $(p=0.037)$. There are significant association between fracture $(p=0.027)$, bone fragility $(p=0.008)$, spinal pain ( $p=0.016)$ with osteoporosis. Age $(p=0.002)$, blood lead level $(p=0,055)$, calcium consumption $(p=0.022)$ and exercise regularly $(p=0.08)$ were together significant correlation with the occurrence of osteoporosis. These variables increase the risk of osteoporosis, simultaneously. It implies that to prevent osteoporosis, the possible source of lead contamination should be avoided, meanwhile post menopause women shall improve calcium intake and doing exercise regularly.
\end{abstract}

Keywords: Blood lead level, Osteoporosis, Post Menopause Women

\section{INTRODUCTION}

All human being and the environment could not be separated from each other. The contaminated environment often causes The detrimental impact on the health. Otherwise, the human needs become more complex in accordance with the national development and industrialization in a country. The health problems will arise since the development and industrialization is regardless of the environmental aspects. Eco-development and eco-Industrial 
absolutely must be applied to protect the environment and human health.

Lead $(\mathrm{Pb})$ is a heavy metal that is still widely spread in the environment as hazardous substance or element. It is due to this element is still widely used both in industrial activities and household supplies. Sources of lead exposure are obtained from industrial process and fuel utilization, as well as derived from household activities surround us. Some household items were also identified containing lead, such as paint batteries, ceramics, and some cosmetics.

In Indonesia, lead is still used as a gasoline fuel mixture in a type of fuel named "premium" from Marketing Unit V Surabaya which serves the most area of East Java, Bali, West Nusa Tenggara and East Nusa Tenggara is still using lead as an octane booster of 0.01 grams / liter (Tawafurrohim, 2008) The use of lead as a fuel mix as an octane booster actually has been banned by the world. This is due to the health effects caused by lead is very dangerous. There is one location with air lead contamination levels exceed the limit of Indonesian environmental law in Surabaya city (Prasasti, 2008). Regularly contact between human and heavy metals was dangerous. Lead will cause a variety of health effects because this element could not be degradable and persistent in the human body. The inhaled or ingested lead will circulate through the blood flow, and reabsorbed in the kidney and brain, or stored in the bones and teeth.

Osteoporosis is widely spread throughout the world and still as a public health problem. Lead exposure will increase the risk of osteoporosis (Campbell and Auinger, 2007). Lead enters into the human body and then follow the blood circulation, to the tissues and several organs such as the liver, kidneys, lungs, brain, spleen, and heart. After a few weeks, most of the lead in tissues and organs will be mobilized into the bones and teeth. Lead present in the bones for decades but it can be mobilized back into the blood and organs under certain circumstances, especially during pregnancy, lactation, fractures, during osteoporosis, as well as during the growth spurt (ATSDR, 2007,2008,2009). In animal studies, it reveals that high exposure to lead was associated with reduced bone density (Escribano, 1997). It is also consistent with Grubber, et al (1996) who investigated the effects of lead exposure on rat's bone, that 3 months exposure of lead showed a significant relationship with decreasing of in bone density. The high exposure of lead from high emission vehicles might as a risk factor for osteoporosis in Surabaya. This research was to study whether lead exposure influences blood lead level in patients with osteoporosis.

\section{METHOD}

This is a cross-sectional study was conducted in Surabaya, Indonesia. The study sample was 60 postmenopausal women aged 50 to 65 years old, randomly selected from patients Mitra Keluarga Surabaya Hospital in Juli-Desember 2007. Blood samples and bone scan were collected froom every respondent after signing the inform consent. About $\pm 3 \mathrm{cc}$ of venous blood was collected by laboratory staff, and then analyze $\mathrm{Pb}$ blood (whole blood) conducted by Atomic Absorption Spectrophotometry method in the Balai Besar Laboratorium Kesehatan Surabaya (Indonesia accredited laboratory).

Bone density was assessed by scanning the low spine and both of the hips. Osteoporosis examination conducted by Dual X-Ray Absorptiometry (DXA) method for low spine and both of hip. DXA was analysis in the Mitra Keluarga satelit hospital in Surabaya. 
Osteoporosis occurs when the bone density $T<-2.5$, Osteopenia when $-2,5 \leq T \leq-$ 1, Normal T> -1. Data were analyzed using SPSS version 16. Statistical analysis using linear regression and multiple Logistic Regression test.

The ethics committee of the Airlangga University Surabaya Indonesia approved this study (No. 075/PANEC/LPPM/2009). The blood lead level test was taken and analysis on April and May 2009.

The standard threshold of $\mathrm{Pb}$ content in blood according to the WHO is $20 \mathrm{mg} / \mathrm{dL}$ in for adults and $10 \mathrm{mg} / \mathrm{dL}$ for children (KPPB, 2000)

\section{RESULT}

\section{Characteristics of Respondents}

There ware 14 respondents $(23,3 \%)$ in the 65 years old, 7 respondents $(11,7 \%)$ in the 62 years old. The youngest age of the respondents was 50 years old and the oldest was 65 years old, the mean age was 58,75 years old. There were 28 respondents $(46,6 \%)$ finished their senior high school. The most of the respondents (88\%) had their income > Rp.2000,000,00 per month and there was $46,6 \%$ respondents hadn't work anymore.

Respondents in this study were postmenopausal women in the age group 50-65 years. Women have a higher risk of developing osteoporosis than men. Menopausal status was also closely associated with the incidence of osteoporosis. Age is increasingly found osteoporosis ( $p<0.05$ ) (9). Most respondents were in the age group of 65 years $(23.3 \%)$, with 4 respondents $(28.6 \%)$ do not suffer from osteoporosis, 10 respondents (71.4\%) with osteoporosis.

Most of the respondents educational background is senior high school or the equivalent, as many as 28 respondents (46.7\%) with 15 persons (53.6\%) did not have osteoporosis and 13 respondents (46.4\%) had osteoporosis. Respondents in this study most of which 53 respondents (88.3\%) have incomes of more than $\mathrm{Rp}$. 2000.000 , - per month. A total of $46.7 \%$ of respondents in this study had been retired.

Education can influence the understanding of a variety of health problems. Statistical analysis showed no correlation between education ( $p=0.461)$, income ( $p=0.752)$, and the current work status ( $p=0.323$ ) and the incidence of osteoporosis. Although respondents mostly high school educated, but they relatively have high level of income so that access to adequate health care can be met, while those who are still actively working may be more mobile, where moving is a good activity for bone health as well as their socialization allows them to have access to better health information.

The Relationship between the Source of Lead Exposure (Work History, History of residence, vehicle usage history, Canned Food Consuming Habits, Smoking Habit History, Calcium Consumption with Blood Lead Levels (BLL)

There were two groups in work history, they were indoor and outdoor. There were $76,6 \%$ of respondents work indoor. The history of residence showed that $45 \%$ of respondents stayed on $500-1000 \mathrm{~m}$ from the source of pollution. The vehicle usage history from the respondents showed that $48,3 \%$ often use the car (closed vehicle). Canned food identified as the source of $\mathrm{Pb}$. There were $53 \%$ respondents had canned food consumption habits more than once a year. All respondent wasn't the smoking habit history, because they were women and it didn't the culture. The data showed that there were $50 \%$ of respondents usually consume the calcium supplements or drink a calcium milk more than once in a year. 
The mean blood lead level in the respondents are $11.135 \mu / \mathrm{dL}$ with a maximum lead content of $28.95 \mu / \mathrm{dL}$. Regression test showed that work history significantly related to blood lead levels $(p=0,037 ;<0,05)$. Work outdoor allows respondents to get more contact with the sources of environmental lead pollution. Potential sectors affecting air quality in Surabaya city, in general, is the transportation sector.

Respondents' residences were mostly in the range of 500-1000 meter distance. from the pollution source, riding a motorcycle, not in the heavy traffic, rarely consumed canned food, no smoking. Ahough $\mathrm{Pb}$ absorption will increase if there is a deficiency of calcium (10-12), thus $\mathrm{Pb}$ metabolism associated with hormones (13), in this study the source of calcium measured in the frequency. The result of BLL completely saw in table 1.

Table 1. Respondents Blood Lead Level (BLL)

\begin{tabular}{|l|c|c|}
\hline \multirow{2}{*}{ Blood Lead Level } & \multicolumn{2}{|c|}{$\%$} \\
\cline { 2 - 3 } & $\mathrm{n}$ & $13,3 \%$ \\
& 8 & \\
\hline$\geq 20 \mu \mathrm{g} / \mathrm{dL}$ & 52 & $86,6 \%$ \\
& & \\
\hline$\Sigma$ & & $100 \%$ \\
\hline Mean & 60 & \multicolumn{2}{|c|}{11,135} \\
\hline Min & \multicolumn{2}{|c|}{1,932} \\
\hline Max & \multicolumn{2}{|c|}{28,95} \\
\hline
\end{tabular}

The Relationship between Age, Blood Lead Levels, Calcium intake, Alcohol consumption, Caffeine consumption, Exercise habits, Body Mass Index (BMI) with the occurence of Osteoporosis.

The results of Multiple Logistic Regression test showed that blood lead levels (BLL) have a significant association with the occurrence of osteoporosis ( $p=0.055)$ along with variable of age $(p=0.002)$, the consumption of milk or calcium supplement $(p=0.022$ ) and exercise habits $(p=0.008)$. The adult blood lead level standard of the World Health Organization (WHO) was $20 \mu / d L$. There are several women that exceed WHO regulation. The high of blood lead level showed that there are several risks for the health. The result of Dexa Bone Densitometer was completely seen in table 2, Fig 1 and Fig 2.

Table 2. The result of Dexa Bone Densitometer

\begin{tabular}{|l|c|c|c|}
\hline Bone & Status & \multicolumn{2}{|c|}{} \\
\cline { 3 - 4 } $\begin{array}{l}\text { Mineral } \\
\text { Density } \\
\text { (T-Score } \\
\text { hips and } \\
\text { spine) }\end{array}$ & & $n$ & $\%$ \\
\hline T>-1 & $\begin{array}{c}\text { Not } \\
\text { Osteoporosis ( } \\
\text { Normal and } \\
\text { osteopenia) }\end{array}$ & 35 & $58,3 \%$ \\
\hline$T<-2,50$ & Osteoporosis & 25 & $41,6 \%$ \\
\hline$\Sigma$ & & 60 & $100 \%$ \\
\hline
\end{tabular}

In which any increase in blood $\mathrm{Pb} 1 \mathrm{~g} / \mathrm{dL}$, the risk of osteoporosis increased 0,848 with increasing age, did not take calcium and exercise (table 3). The blood lead level together with other variables such as age, calcium consumption, and exercise habits had an association with the osteoporosis.

From the results of statistical analysis showed that each increase in age will increase the risk of osteoporosis by 1.5 times, people who never consume milk or calcium supplements had 1.6 times the risk of developing osteoporosis than those who frequently consume, and people who never do exercise have 30.8 times the risk of 
developing osteoporosis than people who exercise regularly three times a week.

Table 3. Multiple Logistic Regression age, BLL, calcium consumption, exercise habits, BMI with osteoporosis. The Pearson and Spearman correlation between age, calcium consumption, exercise habits and BLL

\begin{tabular}{|c|c|c|c|}
\hline \multirow[t]{2}{*}{ Variable } & \multicolumn{2}{|c|}{$\begin{array}{l}\text { Multiple } \\
\text { Logistic } \\
\text { Regression }\end{array}$} & \multirow{2}{*}{$\begin{array}{c}\text { Pearson and } \\
\text { Spearman }\end{array}$} \\
\hline & $\mathbf{P}$ & OR & \\
\hline Age & 0,002 & 1,5 & 0,38 \\
\hline $\begin{array}{l}\text { Blood lead } \\
\text { level }\end{array}$ & 0,055 & 0,848 & \\
\hline $\begin{array}{l}\text { Calcium } \\
\text { consumption }\end{array}$ & 0,022 & & 0,021 \\
\hline often & & 1,6 & \\
\hline Exercise habits & 0,008 & & 0,044 \\
\hline Rarely & & 30,8 & \\
\hline $\begin{array}{l}\text { Body Mass } \\
\text { Index }\end{array}$ & 0,211 & & \\
\hline
\end{tabular}

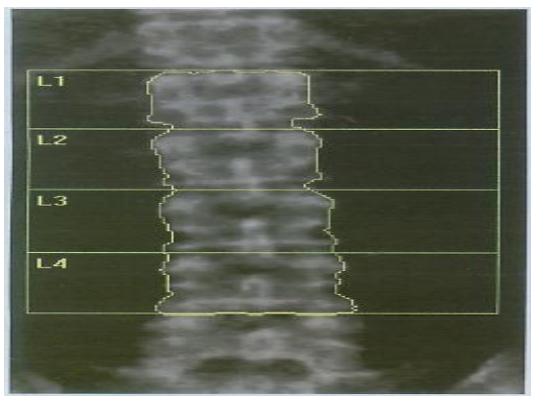

Fig 1. Spine Osteoporosis

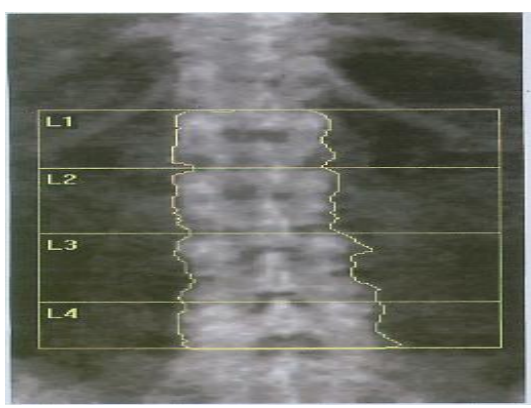

Fig 2. Normal Spine Osteoporosis

The Relationship Between fracture, hunchback, reduced height, back pain with the Occurrence of Osteoporosis
Fracture, hunchback, reduce height, back pain was the sign of osteoporosis. The Multiple logistic regression showed that fracture, hunchback and back pain sign were correlated with osteoporosis. Bone loss increases the risk of fractures $(p=0.027)$, hunchback ( $p=0.008)$ and back pain $(p=$ 0.016). This is due to the decline in bone mass.

\section{DISCUSSION}

Lead $(\mathrm{Pb})$ can enter the body through the respiratory tract, absorption and digestive tract (ingestion). $\mathrm{Pb}$ distributed into 3 main parts of the body, that is blood, Soft Tissue and Bone (EHC WHO, 2006). Pb deposited in bone. As much as $90-95 \% \mathrm{~Pb}$ that entered the body accumulated in bones, a little stored in the brain (Barry and Mossement, 1970). $\mathrm{Pb}$ has a long half-life in bone, especially in people who were exposed to lead in the past and for a long time.

The results of this study showed that blood lead levels were significantly associated with the occurrence of osteoporosis. Blood lead level for an adult was $\leq 10 \mu \mathrm{g} / \mathrm{dL}$ (ATSDR, 2013). The respondents were shown that their blood lead level was more than $10 \mu \mathrm{g} / \mathrm{dL}$ and they had osteoporosis. $\mathrm{Pb}$ absorbed by bone. $\mathrm{Pb}$ is known to have an effect on osteoblasts, osteoclasts and kondrocit, which affected by osteoprosis (Carmouche, 2005). Studies on animals showed that a rise in $\mathrm{Pb}$ exposure degraded bone density (Gruber, 1996), inhibited osteoblastogenesis and decreased bone strength (Ronis, 2001). There is a relationship between the Infant mean blood $\mathrm{Pb}$, with mothers who have high blood lead levels in the median cohort $7.7 \mu \mathrm{g} / \mathrm{dL}$, which infant has a shorter body length of $2 \mathrm{~cm}$ at the age of 15 months, compared with mothers who not exposed to $\mathrm{Pb}$ (Shukla, 1989 ). 
Levels of $\mathrm{Pb}$ blood describe the movement of $\mathrm{Pb}$ from the bones into the bloodstream. If there is a process of bone resorption, $\mathrm{Pb}$ from the bone will be released into the blood. $\mathrm{Pb}$ Blood is also an indicator of exogenous $\mathrm{Pb}$ exposure that is happening and $\mathrm{Pb}$ exposure in the past that stored in bones (Hu et al, 1998). Although 90-95\% Pb stored in bones (Campbell and Auinger, 2007), Pb will lead to blood flow in certain conditions such as pregnancy, lactation, osteoporosis etc (Squib, 1997).

This results of this result also consistent with the results other research that there is a relationship between lead exposure in the past with the occurrence of osteoporosis (Campbell and Auinger, 2007), Bone Mineral Density was significantly associated with the amount of lead in the blood (Nash, 2004), and low bone mineral density in children associated with $\mathrm{Pb}$ blood serum (Riedt, 2009).

There was a relationship between lead exposure in the past with the occurrence of osteoporosis (Campbell and Auinger, 2007). The Bone Mineral Density (BMD) was significantly associated with the amount of lead in the blood (Nash, 2004), and The a low BMD in children associated with $\mathrm{Pb}$ blood serum (27).

From these results, there are possibilities that in the past, respondents had been exposed by $\mathrm{Pb}$, furthermore, $\mathrm{Pb}$ deposited into bones. Then when they get older, in line with the weakening of the balance in the bone remodeling process, $\mathrm{Pb}$ mobilized into the blood. $\mathrm{Pb}$ is toxic to soft tissues and organ systems (4-6). At the low level of toxicity, $\mathrm{Pb}$ has been able to influence the body's biochemical processes.

The risk of osteoporosis will increase with increasing age, but indeed it also influenced by other factors. Bone remodeling process in a young adult is on balance and will be declined in line with increasing age so that the risk of osteoporosis will be higher.

Nutrition plays an important role in health including bone mass and fracture risk. $\mathrm{Pb}$ has a role as a calcium antagonist, which is calcium intake will reduce the absorption of $\mathrm{Pb}$ in adults and animals(4-6). There is a relationship between calcium intake with the decrease of blood $\mathrm{Pb}(\mathrm{P}=0.02)$ (Yuan et al, 2004).

Exercise dosage must be appropriate because if it is too light it will not be used and if it is too heavy it will be dangerous. Cooper et al 1988; Snelling et al 2001 said that Physical activity is proven to lower the risk of hip fractures (Campbell and Auinger, 2007). People who are too lazy to move or exercise will obstruct the process of its osteoblast (the process of bone formation). In addition, bone mass density will decrease. The more movement and exercise, the muscles will spur bone to form a mass. Bass et al said that Observations conducted on athletes showed that athletes had higher $\mathrm{BMD}$ than the people that did a rare exercise (WHO, 2003).

$\mathrm{Pb}$ levels $<20 \mathrm{mg} / \mathrm{dL}$ are supposed to influence the metabolism of vitamin $D$ in the body, while $\mathrm{Pb}>30 \mu \mathrm{g} / \mathrm{dL}$ has been able to interfere with bone metabolism (Brasslow et al, 2002).

Osteoporosis can be called as a thief in the night, people who suffered from osteoporosis do not feel a specific soreness. It will be felt when the bones are fractured that will cause pain, deformity, and impaired function.

A detailed history of patient risk factors is helpful in establishing the diagnosis. Analysis of risk factors is important to determine whether the examination of bone mineral density (BMD) needed or not, which is important to establish the diagnosis.

Fractures, hunchback, back pain, reduced height are the signs of osteoporosis. If the 
bone density is greatly reduced, the bones will be crushed, so that will develop bone pain and deformity. The destruction of the spine will cause chronic back pain. Fragile spine might be destroyed spontaneously or due to minor injuries. Pain will arise suddenly and felt in certain areas of the back, and the pain will be increased if the patient standing or walking. If some spine shattered, it will form an abnormal curvature of the spine (Dowager's hump), which causes muscle tension and pain.

\section{CONCLUSION AND SUGGESTION}

Work history is associated with blood lead levels. Fracture, humpback, and back pain are the sign of osteoporosis. Age, blood lead level, calcium consumption and exercise habits were together significant correlation with the occurrence of osteoporosis. Age, Blood lead Level, calcium consumption and exercise habits were the factors to increase the risk of osteoporosis.

Keep a healthy lifestyle such as avoiding contact with the sources of $\mathrm{Pb}$ pollution, meet the needs of calcium, and regular exercise to prevent osteoporosis.

\section{CONFLICT OF INTEREST}

The author declares there is no conflict of interest regarding the publication of this paper.

\section{ACKNOWLEDGMENT}

The Author would like thanks to Prof. Dr. Djoko Roeshadi, dr., SpOT., FICS, and Prof. Dr. H.J. Mukono,dr., MS., MPH for discussion.

\section{REFERENCES}

Agency for Toxic Substance and Disease Registry. ToxGuide TM For Lead Pb cas\# 7439-92-1. (2007) US Department of
Health \& Human Services PH Service. October. www.atsdr.cdc.gov.

( 2013.01.09)

Agency for Toxic Substance and Disease Registry. (2007). Public Health Statement for Lead. The US. Department of Health and Health Services. $\mathrm{PH}$ services. http://www.atsdr.cdc.gov. (2014.01.10)

Agency for Toxic Subtances and Disease Registry. (2007). Lead Toxicity Who Is at Risk of Lead Exposure. http://www.atsdr.cdc.gov/csem/lead/p bwhoisat_risk2.html. (2014.01.09)

Agency for Toxic Substances and Disease Registry. (2008). Department of Health Service and Human Services, Public Health Service. Division of Toxicology and Environmental Medicine. www.atsdr.cdc.gov. (2014.01.09)

Agency for Toxic Substance and Disease Registry. (2013). Reference Blood Lead Level for Adult in the U.S.

www.cdc.gov/niosh/topics/ABLES/pdfs/ ReferenceBloodLevelforAdults 2013-1022.pdf ( 2013.01.09)

Barry P.S.I, D.B Mossman. (1970). Lead Concentration in human tissue. British Journal of Industrial Medicine. Vol.27 (p):339-351. doi:10.1136/oem.27.4.339. http://oem.bmj.com/cgi/content/abstra ct/27/4/339. (2013.02.09)

Brasslow, L, et al. (2002) Ensiklopedia of Public Health. Macmillan Reference USA. New York.

Campbell JR, and Auinger P. (2007). The association between blood lead levels and osteoporosis among adults: Results 
from the Third National Health and Nutrition Examination Survey (NHANES III). Environmental health perspectives Journal; (P). 1018-1022.

Carmouche J et al. (2005). Lead exposure inhibits fracture healing and is associated with increased chondrogenesis, delay in cartilage mineralization, and a decrease in osteoprogenitor frequency. Environmental health perspectives. (p); 749-755.

Environmental Health Criteria 234. EHCWHO. (2006). Elemental Speciation In Human Health Risk Assessment. http://www.inchem.org/documents/ehc /ehc/ehc003.htm. (2013.01.09)

Escribano A, et al. (1997). Effect of lead on bone development and bone mass: a morphometric, densitometric, and histomorphometric study in growing rats. Calcif Tissue Int. 1; vol.60 No.2 (p): :200-203.

www.

https://www.ncbi.nlm.nih.gov/pubmed/ 9056171. (2015.09.02)

Gruber HE, et al. (1996). Osteopenia induced by long-term, low-and highlevel exposure of the adult rat to lead. Miner Electrol Metabolism. Vol.23 no.2 (p):65-73.

Hu H, Rabinowitz M and Smith D. (1998) Bone lead as a biological marker in epidemiologic studies of chronic toxicity: conceptual paradigms. Environmental Health Perspectives. Vol.106 no. 1 (p):106

Komite Penghapusan Bensin Bertimbal. (2000).http://www.kpbb.org/download/
Dampak\%20Pemakaian\%20Bensin\%20B ertimbel\%20dan\%20Kesehatan.pdf. (2009.02.09)

Michael A., Lead, and Food. (2008) http://www.extension.umn.edu/info u/nutrition/BJ652.html. (2012.02.10)

Muhammad I, Olgavivera B. (2005) Identifikasi Osteoporosis pada Berbagai Kelompok Umur dengan Morfometri Femur dan Metakarpal. Jurnal Medika Nusantara. Vol.26. No.4 (p):230 234.

Napitulu. (2008) Pengaruh Pemberian Kalsium Secara Oral Terhadap Kadar Plumbum Dalam Darah Mencit (Mus Musculus L). Tesis. http://library.usu.ac.id/ (2013.05.14)

Nash D, et al. (2004). Bone Densityrelated Predictors of Blood Lead Level among Peri-and Postmenopausal Women in the United States The Third National Health and Nutrition Examination Survey, 1988-1994. American journal of epidemiology. Vol 160. No. 9. (p):901-911.

Prasasti Cl. (2008). Modeling lead (Pb) Air pollution with Blood Lead Level (BLL) in street children in Surabaya City. Thesis. Airlangga University Surabaya.

Popovic Marija; et al. (2005). Impact Of Occupational Exposure on Lead Level in Women. Environ Health Perspective. Vol.4 (p):478-487. http://www.ncbi.nlm.nih.gov/pmc/articl es/ PMC 12784889/. (2014.01.11)

Riedt CS, et al. (2009). Blood lead levels and bone turnover with weight reduction in women. Journal of Exposure 
Science and Environmental

Epidemiology. vol.19. no.1 (p):90-96.

Ronis MJ, et al. (2001). Skeletal effects of developmental lead exposure in rats. Toxicological Sciences. Vol.62. no.2 (p); :321-329.

Shukla $R$, et al. (1989). Fetal and infant lead exposure: effects on growth in stature. Pediatrics. vol.84 no.4. (p):604612.

Squibb Katherine., (1997). Applied Toxicology. NURS 735. METALS. • Lead. pdf.

http://www.osti.gov/eprints/topicpages /documents/record/223/2510068 (2013.01.09)

Tawafurrohim. (2008). Bensin di Jawa Timur Masih Berkadar Timbal. Tempointeraktif 22/9/2008. www.tempointeraktif.com. (2009.01.02)

WHO., (2003). Scientific Group. The Burden of Musculoskeletal Conditions at the Start of the New Millenium. WHO Technical Report Series 919. Geneva: World Health Organization. http:// whqlibdoc.who.int/trs/WHO_TRS_919.p df. (2014.10.08)

Yuan Zhuang, Lei Hong, Zhu Tian Yu, Liang Min, Chen Hai Bo., (2004). Correlation of Bone Mass Density with Serum Selenium, Zink, Ferrum, Calcium, Plumbum and Alkaline Phosphatase in 95 Children. Chinese Journal of Clinical Nutrition. Vol. 12 No. 4 (p): 232-234. http://www.cjen.cn/cjen1/15.pdf. (2013.02.10) 